Article

\title{
Social Surveys about Solid Waste Management within Higher Education Institutes: A Comparison
}

\author{
Navarro Ferronato ${ }^{1}$, Carolina D'Avino ${ }^{2}$, Marco Ragazzi ${ }^{3}$, Vincenzo Torretta ${ }^{1, *}$ \\ and Giovanni De Feo ${ }^{2}$ \\ 1 Department of Theoretical and Applied Sciences, University of Insubria, Via G.B. Vico 46, I-21100 Varese, \\ Italy; nferronato@uninsubria.it \\ 2 Department of Industrial Engineering, University of Salerno, Via Giovanni Paolo II 132, I-84084 Fisciano, \\ Italy; carolinadav@tiscali.it (C.D.); g.defeo@unisa.it (G.D.F.) \\ 3 Department of Civil, Environmental and Mechanical Engineer, University of Trento, Via Mesiano 77, \\ I-38050 Trento, Italy; marco.ragazzi@unitn.it \\ * Correspondence: vincenzo.torretta@uninsubria.it; Tel.: +39-0332-218-782; Fax: +39-0332-218-779
}

Academic Editor: Elena Cristina Rada

Received: 16 January 2017; Accepted: 3 March 2017; Published: 7 March 2017

\begin{abstract}
Solid waste mismanagement is a social burden that requires the introduction of reliable public policies, including recycling principles and technological facilities. However, the development of recycling plans is a real issue for municipal governments, since it involves psychological and cultural factors, both in developed and developing countries. Questionnaire survey is an important tool for evaluating which solid waste management policy is suited for each specific study area, involving citizens and stakeholders. The aim of this paper is to evaluate what approach should be applied for social surveys in higher education institutes, comparing developing and developed countries. Italy is the developed country analyzed, where two universities in different cities are compared, while La Paz (Bolivia) is the emerging reality considered. The research conducted in La Paz led us to understand that, although recycling rates are low (about 8\%), many students $(56.96 \%)$ separate up to half of the waste produced at home. At the same time, about $53 \%$ of those interviewed do not know the recycling practices implemented by the informal sector which is the one that constantly act for improving the recycling rates of the city. Low technological acceptance is instead underlined in the high income country, since there is a common negative opinion concerning the introduction of landfills and incinerators near residential areas (49\% disagree). A comparison of the methodologies adopted for the two case studies is introduced whereas investigations results are presented.
\end{abstract}

Keywords: higher education institutes; developing countries; recycling behavior; social survey; municipal solid waste management

\section{Introduction}

The lack of solid waste management (SWM) activities is an environmental and social burden worldwide [1,2] although public attention in environmental aspects is an increasing behavior [3]. Since final disposal is viewed as a secondary actor in the future scenarios of municipal solid waste (MSW) [4], nations' key policies are introducing concepts as reduce, reuse, and recycle (3Rs), integrated management, and industrial ecology, in developed [5] as in emerging countries [6]. The improvement of 3R principles within the community can reduce the usage of land for waste disposal, decreasing expenditure on SWM and minimizing the generation of waste [7], at the same time improving the useful life and the environmental sustainability of the final disposal sites [8]. The implementation of this approach has not been currently developed in the majority of low income countries due to 
the low financial sustainability, lack of public awareness, and lack of reliable polices [9-13]. Selective collection and optimization of waste flux are necessary for achieving an effective reduction of waste and environmental impacts [14]. To that purpose, users' and households' inclusion in recycling activities, who contribute constantly to the production of, is essential and recommended [15] as a high-quality recycling service is a function of a strong community perception of MSW practices [16]. Indeed, the introduction of recycling policies is a real public issue [17] and includes psychological and cultural factors [18] besides environmental, climatic, and economic variables [3].

Public awareness and attitudes to waste can affects all stages in the SWM process, as noted in other studies [9]. There are three measures to encourage users' and partners' involvement: information diffusion, awareness campaigns, and tax incentives [19]. Indeed, the strategies which emphasize individuals' intrinsic and moral motivation to recycle and correctly manage MSW are imperative for promoting household waste reduction behavior [13]. Introduction of sensitivity campaigns [10] and economic incentives for those who demonstrate the best collection results [20] are recommended in order to achieve high recycling rates. The lack of direct benefits, low public awareness, and lack of organized collection and planning do not encourage public collaboration, in particular among those who are not interested in environmental issues [21]. As a result, many studies encourage municipalities to introduce economic benefits, associated with high recycling rates [22], for reducing environmental impacts and improve the collection system.

MSW management includes physical components and management issues that need to be addressed, such as the strategic planning, public participation, and financial management. Moreover, the high number of stakeholders and actors involved in the collection and treatment systems increase the difficulty in planning and structuring reliable programs; political, institutional, social, and technical aspects should always be included [23]. The level of public awareness and attitudes towards waste do not affect only the quantity and nature of waste generated, but also its final destination, decreasing recycling behavior, especially in low-income countries.

Many studies suggest that pro-recycling attitudes are influenced firstly by having appropriate opportunities, facilities, and knowledge to recycle, and secondly by not being deterred by physical issues for recycling (i.e., time, space, and inconvenience) [24]. The willingness to participate in waste recycling is usually common, however local recovering services are mostly too unreliable and inconvenient to allow users and potential users to do so comprehensively [25]. So, the predictors of recycling activity and good management are essentially logistical. Having access to a structured curbside recycling facility, as well as good knowledge of this facility, and perceiving that recycling is easy and convenient are crucial factors for predicting recycling behavior [26]. Feedback mechanisms should be introduced to increase user inclusivity and provide useful indications about current MSW management system equity and reliability [27]. In addition, large-scale house-to-house publicity of local recycling opportunities has a demonstrable positive effect, although for achieving high recycling targets all households need to be convinced of the need to recycle [28].

Within developing and developed countries, the weaker categories in environmental themes seem to be always older people and citizens with low education levels that cannot reach information from media and multimedia tools [29]. On the contrary, younger and adults respect environmental issues because they are sensitive to modern 'green' approaches [30] and to educational aspects that include respect of laws and sustainable public cohabitation [31]. Recycling behavior and public participation can improve whether citizens receive information about the benefits of recycling, the methods to sort the waste, and new programs [32]. The need to investigate the association between action planning and long-term household waste behaviors is expressed in many studies [13] and social surveys are mostly the methods used [33,34].

Generally, universities and schools are appropriate areas for introducing sensitivity campaigns, in order to achieve a global consciousness concerning environmental issues, since they are principal sources of knowledge and culture $[35,36]$. Thus, public education infrastructures have a main role to increase environmental awareness within public opinion [37] and to promote education in sustainable 
development as implemented in other realities [38]. Universities campuses, due to their large size and number of people that live daily within the area, can be considered "small cities" [39] and many higher education institutes can generate significant environmental and social impacts [40] through both direct and indirect activities [41]. The inclusion of students, professors, and administrative staff within the SWM system is recommended for achieving the so called 'green university' [42]. As a result, the implementation of social surveys within public educational institutes is really important and can be used as a supported and preliminary tool to evaluate public behavior and population awareness [43].

The aim of this work is to compare social awareness within universities of developed and developing countries, with high and low recycling rates respectively, in order to understand which approaches are missing in these areas in terms of environmental sustainability in SWM. In this paper, we discuss students' attitudes to recycle and interests in solid waste issues through a questionnaire survey. The objective is to understand which are the main difficulties for introducing sustainable approaches and main weaknesses that should be solved in order to develop waste reduction targets, promotion of waste separation activities, and the vision of 'zero-waste', as proposed in other case studies worldwide [1,44].

This study comprehends two main field works: one in the city of Varese (Italy) and another in La Paz (Bolivia). The Salesian University is the higher education institute where the survey has been carried out in La Paz while the University of Insubria is the institute considered in Varese. The questionnaire surveys were carried out in a period of about one month, in February 2016 and in October 2015 respectively, taking into account specific social and environmental characteristics of the study areas. Indeed, the questionnaires are different between the two cases, assessing different habits in solid waste practices and considering dissimilar recycling rates. The comparison allows an understanding of which issues are mainly presented and which measures should be introduced. Moreover, to complete and enrich the investigation, Varese has been compared with the University of Salerno [45] where the same study was implemented first. These two Italian realities differ in terms of geographical area and population habits since Varese is a northern city of Italy and Salerno is a southern one. However, both are similar regarding recycling rates $(60 \%-65 \%)$. The comparison between the investigations has been analyzed qualitatively, in order to identify strengths and differences between each one, while questionnaire results are presented in percentage and differences between the methodologies used for the surveys are highlighted. This approach is significant to understand similarities and differences between high and low income countries, with high and low recycling rates, and to detect different needs required to improve MSW management in both regions.

The next section presents the methodology applied for the social survey, giving a brief overview of the study area and of the participants that took part of the interviews, while a list of the questions suggested within both questionnaires is provided. In Section 3, the results are summed up, first describing a comparison between knowledge and opinion introduced by the students of Varese and Salerno. Following this, the results of the survey conducted in La Paz are presented including a comparison with the Italian case study. Section 4 contains the discussion about the surveys, giving strengths and weaknesses of the study presented. Finally, Section 5 provides the conclusion and some useful remarks for stakeholders and actors involved in SWM.

\section{Method}

\subsection{Study Areas}

\subsubsection{The Italian University}

The survey has been carried out at the Insubria University of Varese (Engineer, Science, Law, and Economics Departments), that totally count 9186 students (2015) dislocated in four main locations, in four different cities. The questionnaires were administrated only at the Varese institute, where the students mainly come from the district of Varese, Milan, Como, and surrounding villages. Though located in a developed high-income area, the Insubria University is relatively young, having been 
founded in 1998. Varese is a city of northern Italy, located within the Lombardia region. It counts 80,799 inhabitants with a population density of 1473.36 inhabitants $/ \mathrm{km}^{2}$ [46]. The average altitude is $382 \mathrm{~m}$ above sea level and the city covers an area of $54.84 \mathrm{~km}^{2}$. In the current year, Varese SWM service achieved a $63 \%$ of recycling rate, exceeding the Italian average.

\subsubsection{La Paz as an Emerging Reality}

La Paz, with about 789,585 inhabitants [47], is one of the most populous cities in Bolivia. It is located between the Andean plateau and the Amazon region, placing the city in an environmentally sensitive area for anthropic activities. The average altitude is $3640 \mathrm{~m}$ above the sea level and the surface covered by the city is $1986 \mathrm{~km}^{2}$, with a population density of 478 inhabitants $/ \mathrm{km}^{2}$. For the World Bank, Bolivia is a low-middle income country, however La Paz is facing with the typical issues of an emerging city: urban area expansion, economic improving, and governmental re-organization, among others. Nevertheless, development of waste management services is still lacking in facilities and improved systems, since the recycling rate is low and mostly provided by the informal sector.

The Salesian University of La Paz located here was founded in 1998, similar to the Insubria University although for different reasons: to improve social sustainability in a poor area of the city. It is a private institute where around 6000 students, from El Alto and La Paz, study in careers like Law, Economics, Engineering, and Sociology. Officially recognized by the Education Ministry, it is a higher education institution formally affiliated with the Christian-Catholic religion. The university provides several academic and non-academic facilities and services, including a library and an administrative secretary. In addition, around the area, restaurants, bars, and stationary shops are located, identifying Salesian University as one of the most important University of La Paz.

\subsection{Participants}

\subsubsection{The Italian Case}

At University of Insubria, 337 students were interviewed randomly in the areas around the university structures. The departments involved were Law, Environmental and Chemical Science, Civil and Environmental Engineering, Medicine, and Economics. In 2015, enrollment figures within the departments were 872, 932, 356, 797, and 400 respectively, totaling 3357 of 9206 Insubria students [48]. So, the percentage sample size is $10 \%$ considering the faculties involved and $3.6 \%$ considering the university. The confidence level supposed in this social survey is equal to $95 \%$ and the confidence interval obtained is equal to $5.06 \%$. Relatively to the sample per faculty, the students interviewed were $59,52,93,83$, and 50 , corresponding to $6.8 \%, 5.6 \%, 26 \%, 10 \%$, and $12.5 \%$ of the students of Law, Environmental and Chemical Science, Civil and Environmental Engineering, Medicine, and Economics, respectively.

\subsubsection{The Students of La Paz}

A random sample of 200 students from the carriers of Law, Psychomotricity, and Educational Science were interviewed. However, only 158 lived in La Paz, therefore only this sample was considered in the assessment. The sample is composed of 35 students of Law, 81 of Psychomotricity and 35 of Science and represents the $2.6 \%$ of the Salesian University students (about 6000). Data about the number of students of each department were not available for the study, so percentages for each cannot be proposed. The confidence level used is equal to the $95 \%$ and the corresponding confidence interval, with the value obtained for the worst case percentage (50\%), is equal to the $7.69 \%$. The age vary from 17 to 30 years old, with an average of 22 years old, $33 \%$ are students who work during the week and the majority are women $(76 \%)$. All the students were involved in classroom lessons where the questions were explained and fully commented. Moreover, the teachers were allowed to explain to the students the importance of the survey and the reason why it was implemented. 


\subsection{Procedure}

\subsubsection{The University of Varese and Its Comparison with Salerno}

For the Varese case study, the questionnaire suggested by De Feo and Williams has been implemented [45]. Ten questions are introduced, each with four answers coded from 1 to 4, with the fourth that always represents the answer 'I do not know' (Table 1). The survey took place in October 2015, and the questionnaires were provided to the students from Monday to Friday for four weeks, during the morning time until 3 p.m., outside and inside the campus structures such as school canteens, bars, classrooms, corridors, and green areas. Afterwards, the investigation applied in Varese has been compared with the study suggested by De Feo and Williams [45] at the University of Salerno, located in the Campania region in the south of Italy, where 900 students were interviewed. Though the two samples have different dimensions, it is possible to compare the data for the proportion respected by the studies. Indeed, both are about $2 \%-3 \%$ of the dimension of each university and are located in areas where the recycling rate exceeded $60 \%$. The questions allow us to understand:

- $\quad$ opinions about waste management issues

- $\quad$ knowledge about waste recovery and recycling

In particular, in the first part of the questionnaire, opinions about the construction of treatment plants within the area (e.g., incinerators, landfills) were considered, while in the second part the preparation degree about waste composition, quantities collected, and final life of each fraction were measured, according to De Feo and Williams [45].

Table 1. Face-to-face questionnaire administrated by De Feo and Williams [45] and provided to the students of the University of Salerno and Insubria.

\begin{tabular}{|c|c|c|c|}
\hline Aspect & No. & Question (Q) & Choices for Each Question $\left(A_{i}\right)$ \\
\hline \multirow{5}{*}{ Opinion } & Q1 & $\begin{array}{l}\text { What do the components separated } \\
\text { from MSW represent to you? }\end{array}$ & $\begin{array}{l}\text { Discards to dispose of in landfill; Materials to } \\
\text { recycle; Waste to incinerate; I do not know }\end{array}$ \\
\hline & Q2 & $\begin{array}{l}\text { Would you agree to a landfill being } \\
\text { constructed in your city? }\end{array}$ & $\begin{array}{l}\text { Yes; No; Yes, if for my city it is the best among } \\
\text { alternatives; I do not know }\end{array}$ \\
\hline & Q3 & $\begin{array}{l}\text { Would you agree to an incinerator } \\
\text { being constructed in your city? }\end{array}$ & $\begin{array}{l}\text { Yes; No; Yes, if for my city it is the best among } \\
\text { alternatives; I do not know }\end{array}$ \\
\hline & Q4 & $\begin{array}{l}\text { Which of these factors leads us to } \\
\text { more readily give away a product } \\
\text { with it subsequently becoming waste? }\end{array}$ & $\begin{array}{l}\text { Low educational level; Lack of environmental } \\
\text { awareness; High income; I do not know }\end{array}$ \\
\hline & Q5 & $\begin{array}{l}\text { Who among these actors have to be } \\
\text { the part of the siting process of a } \\
\text { landfill or an incinerator? }\end{array}$ & $\begin{array}{l}\text { Only technicians; Both technicians and } \\
\text { politicians; Technicians, politicians, and } \\
\text { citizens; I do not know }\end{array}$ \\
\hline \multirow{5}{*}{ Knowledge } & Q6 & $\begin{array}{l}\text { What is the MSW component with the } \\
\text { highest weight percentage? }\end{array}$ & Plastic; Glass; Putrescible; I do not know \\
\hline & Q7 & $\begin{array}{l}\text { What is the average daily production } \\
\text { of MSW per capita? }\end{array}$ & $150 \mathrm{~g} ; 1.5 \mathrm{~kg} ; 15 \mathrm{~kg}$; I do not know \\
\hline & Q8 & What is compost? & $\begin{array}{l}\text { A container for MSW collection; A particular } \\
\text { chemical compound; A kind of fertilizer; } \\
\text { I do not know }\end{array}$ \\
\hline & Q9 & What does RDF mean? & $\begin{array}{l}\text { Recycling domestic factory; Refuse derived } \\
\text { fuel; Reuse domestic facility; I do not know }\end{array}$ \\
\hline & Q10 & $\begin{array}{l}\text { Which waste material cannot be } \\
\text { recycled indefinitely? }\end{array}$ & Glass; Aluminium; Paper; I do not know \\
\hline
\end{tabular}

\subsubsection{The Survey Introduced for the Salesian University of La Paz}

For the La Paz case study, a specific questionnaire has been proposed. At first, a questionnaire with 73 questions were introduced to the students: The questions were divided in six groups for evaluating general awareness about ecology and environmental issues, collection and treatment service perception, city organization and efficiency, knowledge about regulations and public campaigns, opinion about 
city cleanness, and about selective collection and recycling. The survey took place in eight classes with an average of 30 students each. The questionnaires were provided to the students after a $10 \mathrm{~min}$ presentation, where the motivation of the survey and rules for questionnaire completion were provided. The students completed the survey in an average time of $20 \mathrm{~min}$, after which they were introduced to environmental subjects that provided information on topics which they were not prepared on: recycling treatment, composting facilities, environmental pollution.

In this paper, only a group of 10 questions are presented, concerning only the subject of MSW management and representative for studying the condition of the SWM in an emerging city (Table 2). Similarly, with the questionnaire introduced for Italian case studies, the questions were chosen and provided in order to evaluate opinions and behavior in different themes:

- $\quad$ service equality

- recycling behavior

- $\quad$ sensitivity campaigns

- public involvement

- informal sector inclusion

- $\quad$ service quality

- $\quad$ service transparency

Such themes are of particular relevance within emerging cities since are the ones that mostly are not considered into SWM policies introduced by local governments [49]. In addition, such information allow understanding whether the willingness to improve the recycling rate is still present within young citizens or not. The answers suggested are six for each question, except for the last where only the willingness to recycle is evaluate with 'yes' or 'no'. Each answer is converted in a scale from 1 to 6 , where the answer 'I do not know' is always the last. The lower score (1) is the worst answer, while the higher score (5) corresponds to the best situation.

Table 2. Questionnaire provided to the students at the Salesian University of La Paz.

\begin{tabular}{|c|c|c|c|}
\hline Feature & No. & Question (Q) & Choices for Each Question $\left(A_{i}\right)$ \\
\hline $\begin{array}{l}\text { Recycling } \\
\text { behavior }\end{array}$ & Q1 & Quantity of waste separated at home & $\begin{array}{l}\text { Nothing; Something; Half; Many; All; } \\
\text { I do not know }\end{array}$ \\
\hline Service equality & Q2 & $\begin{array}{l}\text { Frequency of the formal waste collection } \\
\text { (per week) }\end{array}$ & $\begin{array}{l}\text { One time; Two times; Three times; } \\
\text { Four times; Five times or more; Never }\end{array}$ \\
\hline $\begin{array}{l}\text { Informal sector } \\
\text { inclusion }\end{array}$ & Q3 & $\begin{array}{l}\text { Are exploitable waste materials recollected } \\
\text { by the informal pickers? }\end{array}$ & $\begin{array}{l}\text { Never; Sometimes; Often; Almost always; } \\
\text { Always; I do not know }\end{array}$ \\
\hline Service equality & Q4 & The collection time satisfy the citizens & $\begin{array}{l}\text { Never; Sometimes; Often; Almost always; } \\
\text { Always; I do not know }\end{array}$ \\
\hline Opinion & Q5 & Efficiency of the collection service & $\begin{array}{l}\text { Very bad; Bad; Good; Very good; Excellent; } \\
\text { I do not know }\end{array}$ \\
\hline \multirow{2}{*}{$\begin{array}{l}\text { Sensitivity } \\
\text { campaigns }\end{array}$} & Q6 & $\begin{array}{l}\text { Are there recycling campaigns organized by } \\
\text { the local Government? }\end{array}$ & $\begin{array}{l}\text { Never; Sometimes; Often; Almost always; } \\
\text { Always; I do not know }\end{array}$ \\
\hline & Q7 & $\begin{array}{l}\text { Are there waste reduction campaigns } \\
\text { within the schools? }\end{array}$ & $\begin{array}{l}\text { Never; Sometimes; Often; Almost always; } \\
\text { Always; I do not know }\end{array}$ \\
\hline $\begin{array}{c}\text { Public } \\
\text { involvement }\end{array}$ & Q8 & $\begin{array}{l}\text { The citizens are involved in the selection of } \\
\text { new waste management policies }\end{array}$ & $\begin{array}{l}\text { No one; Someone; The half of the } \\
\text { population; Many; All }\end{array}$ \\
\hline $\begin{array}{c}\text { Service } \\
\text { transparency }\end{array}$ & Q9 & $\begin{array}{l}\text { Are the Laws about waste } \\
\text { management clear? }\end{array}$ & $\begin{array}{l}\text { Never; Sometimes; Often; Almost always; } \\
\text { Always; I do not know }\end{array}$ \\
\hline $\begin{array}{l}\text { Recycling } \\
\text { behavior }\end{array}$ & Q10 & $\begin{array}{l}\text { Would you like to recycle waste into your } \\
\text { house or work place? }\end{array}$ & No; Yes; I do not know \\
\hline
\end{tabular}

\section{Results}

\subsection{The Comparison of the Two Italian Studies}

Moving from north to south, Italian population differs in habits and culture, suggesting the introduction of different considerations in urban planning and public organization. The aim of the 
comparison is to assess similitudes in local SWM behavior, highlighting how, in the same country, the opinions can change shifting the point of view in different regions. For introducing the evaluation clearly, the results are described in Figure 1, where every answer obtained in the survey applied in Varese is reported and compared with the case of Salerno [45]. Answers that regard opinions are reported in percentages in Table 3 while the ones that represent the knowledge are schemed in Table 4 .

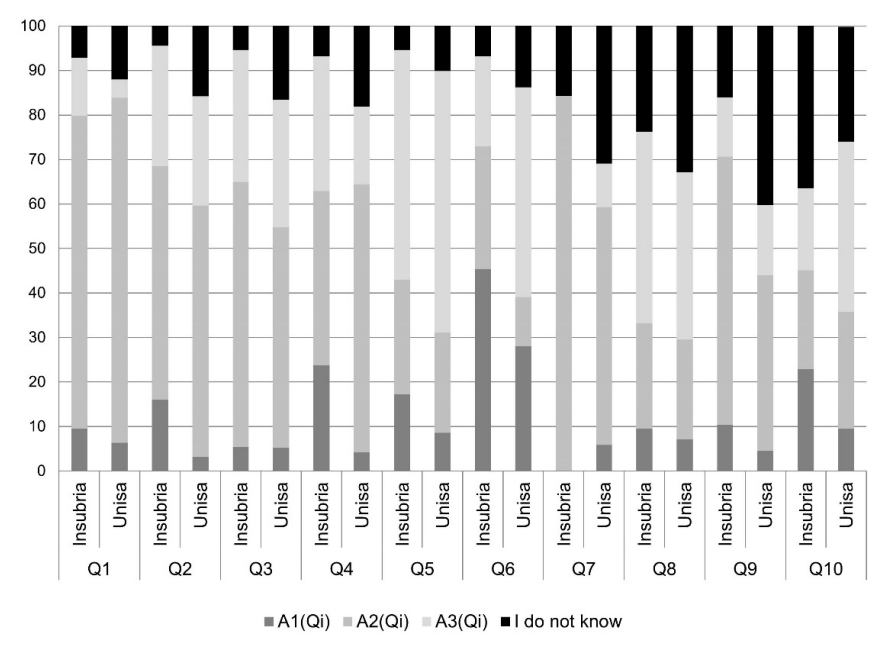

Figure 1. Results, expressed in \%, and comparison of the Italian case studies (Q: Question; A: Answer).

\subsubsection{Opinions}

As is visible in Figure 1 and Table 3, the higher percentages obtained in each opinion are in accordance in both case study. However, for Question 4 ("Which of these factors leads us to more readily give away a good with it subsequently becoming a waste?") the percentage obtained by the University of Insubria (39.17\%), related to answer 2 'Lack of environmental awareness', is significantly lower than the one of University of Salerno (60.11\%). An explanation can be given analyzing income level and public behavior in SWM in northern and southern regions of Italy, where cultural components and different habits affect public opinions. Nevertheless, as suggested by De Feo and Williams [45], there is a common opinion in relation to the introduction of landfills and incinerators near residential areas (Questions 2 and 3). Indeed, the answer 'no' is the most given in both universities and for both technologies (higher than 49\%). As regards public participation, both universities' students agree about the integration of public compounds within policy planning (more than $50 \%$ ). More differences between north and south can be noted as regard knowledge in SWM.

Table 3. Survey results in the Opinions analysis compared between University of Insubria and University of Salerno [45]. The higher percentages are bolded while the lower ones are underlined.

\begin{tabular}{cccccc}
\hline Questions & University & A1 (\%) & A2 (\%) & A3 (\%) & I Do Not Know (\%) \\
\hline \multirow{2}{*}{ Q1 } & Uni Sa & 6.33 & $\mathbf{7 7 . 5 6}$ & $\underline{4.11}$ & 12.00 \\
& Uni Ins & 9.50 & $\mathbf{7 0 . 3 3}$ & 13.06 & $\underline{7.12}$ \\
\hline \multirow{2}{*}{ Q2 } & Uni Sa & $\underline{3.22}$ & $\mathbf{5 6 . 4 4}$ & 24.56 & 15.78 \\
& Uni Ins & 16.02 & $\mathbf{5 2 . 5 2}$ & 27.00 & $\underline{4.45}$ \\
\hline \multirow{2}{*}{ Q3 } & Uni Sa & $\underline{5.22}$ & $\mathbf{4 9 . 5 6}$ & 28.67 & 16.56 \\
& Uni Ins & $\underline{5.34}$ & $\mathbf{5 9 . 6 4}$ & 29.67 & 5.34 \\
\hline \multirow{2}{*}{ Q4 } & Uni Sa & $\underline{4.22}$ & $\mathbf{6 0 . 1 1}$ & 17.56 & 18.11 \\
& Uni Ins & $\mathbf{2 3 . 7 4}$ & $\mathbf{3 9 . 1 7}$ & 30.27 & $\underline{6.82}$ \\
\hline \multirow{2}{*}{ Q5 } & Uni Sa & $\underline{8.56}$ & 22.56 & $\mathbf{5 8 . 7 8}$ & 10.11 \\
& Uni Ins & 17.21 & 25.82 & $\mathbf{5 1 . 6 3}$ & $\underline{5.34}$ \\
\hline
\end{tabular}




\subsubsection{Knowledge}

As regards the second group of questions, which investigate general knowledge in SWM, there is a right answer that must be given for each. However, observing Table 4, the correlation between the responses provided by the two universities is low. Same answers are given in Question 7 ("What is the average daily production of MSW per capita?") and Question 8 ("What is compost?"), where the majority choose the correct choice (A2 and A3, respectively), although University of Salerno scored a lesser percentage $(53.44 \%$ and $37.56 \%$ for Salerno compared to $84.27 \%$ and $43.03 \%$ for Insubria University). Question 6 ("What is the MSW component with the highest weight percentage?") led to understand different solid waste consumption habits between north and south, as in northern Italy plastic waste is more recycled and usually produced [50]. As a result, $45.40 \%$ of Insubria students answered 'plastic' even if the correct answer is 'putrescible waste' (A3), more of the students from Salerno chose correctly (47.11\%). The answer given for question 9 ("What does RDF mean?") is significant: evident is that at University of Insubria there is more knowledge about this theme (the right answer, A2, achieved the 60\%), unlike University of Salerno, where the answer 'I do not know' $^{\prime}$ is the most given. Indeed, Lombardia is the region where Refuse Derived Fuels (RDF) are most consumed and produced in Italy [50], so it is noticeable how local practices influence public knowledge, although not technical or expert in the theme. The last question ("Which of these materials cannot be indefinitely recycled?") identify the real lack of knowledge in both higher education campus. Indeed, the correct answer (A3, 'paper') is the most given only at University of Salerno (only 38\%), while at University of Insubria achieved an even lower percentage (18.4\%). Generally, the answer 'I do not know' is given more time by the Students of Salerno. It can be stated that, despite the high recycling rate achieved in Salerno, more effort should be made by the authorities to improve public awareness in MSW themes, starting with higher education institutes.

Table 4. Survey results in the knowledge analysis compared between University of Insubria and University of Salerno [45]. The higher percentages are bolded while the lower ones are underlined.

\begin{tabular}{cccccc}
\hline Questions & University & A1 (\%) & A2 (\%) & A3 (\%) & I Do Not Know (\%) \\
\hline \multirow{2}{*}{ Q6 } & Uni Sa & 28.00 & $\underline{11.11}$ & $\mathbf{4 7 . 1 1}$ & 13.78 \\
& Uni Ins & $\mathbf{4 5 . 4 0}$ & 27.60 & 20.18 & $\underline{6.82}$ \\
\hline \multirow{2}{*}{ Q7 } & Uni Sa & $\underline{5.89}$ & $\mathbf{5 3 . 4 4}$ & 9.78 & 30.89 \\
& Uni Ins & $\underline{0}$ & $\mathbf{8 4 . 2 7}$ & $\underline{0}$ & 15.73 \\
\hline \multirow{2}{*}{ Q8 } & Uni Sa & $\underline{7.11}$ & 22.44 & $\mathbf{3 7 . 5 6}$ & 32.89 \\
& Uni Ins & $\underline{9.50}$ & 23.74 & $\mathbf{4 3 . 0 3}$ & 23.74 \\
\hline \multirow{2}{*}{ Q9 } & Uni Sa & $\underline{4.56}$ & 39.44 & 15.78 & 40.22 \\
& Uni Ins & $\underline{10.38}$ & $\mathbf{6 0 . 2 4}$ & 13.35 & 16.02 \\
\hline \multirow{2}{*}{ Q10 } & Uni Sa & $\underline{9.56}$ & 26.22 & $\mathbf{3 8 . 2 2}$ & 25.78 \\
& Uni Ins & 22.85 & 22.26 & $\underline{18.40}$ & 36.50 \\
\hline
\end{tabular}

Note: Uni Sa = University of Salerno; Uni Ins = University of Insubria; A = Answer; Q = Question.

\subsection{The Social Survey within La Paz Salesian Universities}

The results obtained are reported in Table 5. Generally, poor opinions about current SWM are introduced by the students. Such reflection can be introduced inasmuch as the answers given by the interviewed are often 'Very bad-Bad-Good", so excluding "Very good and Excellent", for each topic. The diagram with the average score of each question (obtained excluding score 6) is reported in Figure 2. Is visible how the average result for each question suggested did not overcome 3 , which can be considered the sufficient result that should be achieved to considered the issue solved in accordance with public opinions. Survey marks are then presented in percentages in Figure 3. 
Table 5. Survey results at the Salesian University of La Paz. The higher percentages are bolded while the lowers are underlined.

\begin{tabular}{ccccccc}
\hline Questions & A1 (\%) & A2 (\%) & A3 (\%) & A4 (\%) & A5 (\%) & I Do Not Know (\%) \\
\hline Q1 & 15.19 & 28.48 & 28.48 & 13.29 & $\underline{5.70}$ & 8.86 \\
Q2 & 10.76 & 27.85 & 38.61 & $\underline{4.43}$ & 10.76 & 7.59 \\
Q3 & 6.96 & 23.42 & 14.56 & 5.06 & $\underline{3.16}$ & 46.84 \\
Q4 & 8.23 & 41.14 & 20.25 & 15.19 & 8.86 & $\underline{6.33}$ \\
Q5 & 7.59 & 30.38 & 41.77 & 8.86 & $\underline{1.27}$ & 10.13 \\
Q6 & $\underline{2.53}$ & 44.94 & 20.89 & 12.03 & 10.76 & 8.86 \\
Q7 & $\underline{6.33}$ & 34.81 & 20.89 & 12.66 & 17.09 & 8.23 \\
Q8 & 22.15 & 29.11 & 13.92 & 3.80 & $\underline{2.53}$ & 28.48 \\
Q9 & 18.99 & 32.28 & 24.68 & 3.80 & $\underline{1.27}$ & 18.99 \\
Q10 & 10.13 & 72.15 & - & - & - & 17.72 \\
\hline
\end{tabular}

Note: $\mathrm{A}=$ Answer; $\mathrm{Q}=$ Question.

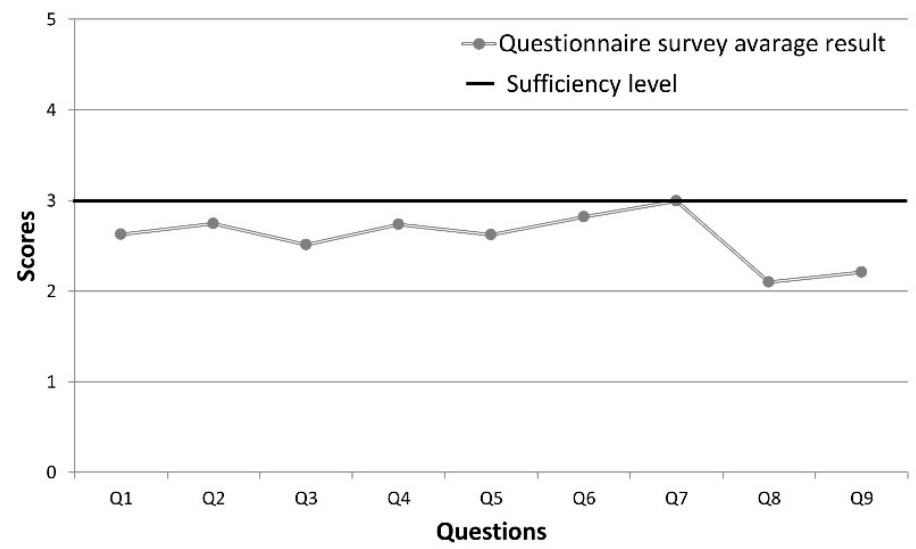

Figure 2. Average scores obtained by the questions from 1 to 9 for the survey applied in La Paz (excluding the score 6: 'I do not know'). The black line represents the 'sufficiency' level.

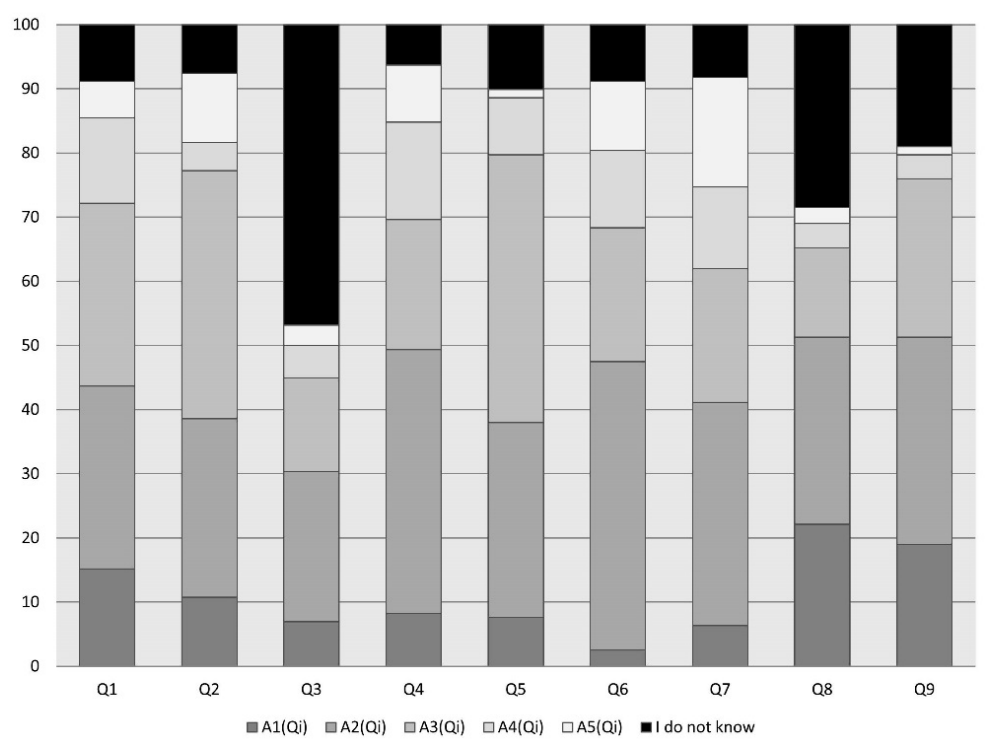

Figure 3. Survey results, expressed in \%, at the Salesian University of La Paz (Q: Question; A: Answer).

Although La Paz recycling rates are low (about 8\%), a part of the students state that at home they separate something (A2) or the half (A3) of the waste produced (totally 56.96\%). The amount 
of separate waste can be delivered at two recycling structures present in the city: waste pickers and informal shops or formal public points for selective collection. Comparing the results obtained with Questions 3 ("Are exploitable waste materials recollected by the informal pickers?") and 6 ("Are there recycling campaigns organized by the local Government?") it can be stated that a few students, who recover recyclable materials, sell exploitable materials to the informal sector (Question 3) while the others deliver it to the formal recycling activities that the government introduced, since 2015, during the weekend of every week (Question 6). Indeed, many students (about 53\%) do not know the recycling practices implemented by waste pickers or affirm that informal activities never occur within the city; Question 3 is the one where the highest percentage of 'I do not know' was obtained. Despite that, there is a part of the students interviewed that know the practice and use it to recycle. Within the city, recovery practices are not common among the citizens, as occurs in developing countries [51], and the awareness campaign should be improved for increasing recycling rate and public awareness. As a result, the quantities separated at home represent only a little fraction that should be recovered. However, encouraging results were obtained by the provision of these questions, as is noticeable how a little recycling chain is just present within the city without big efforts by the local government. Despite that, two main factors can be underlined:

- the informal sector is not well known and recognized by the citizens

- public campaigns are known but not fully respected and applied

Further considerations can be made analyzing Questions 2 (Recollection frequency of the waste per week) and 5 (Efficiency of the collection service). As regards Question 2, except the 38\% of the interviewed who state that the collection is applied three days per week, more than $40 \%$ affirm that the service is provided only two or less days per week, with $7 \%$ answering 'never'. The collection time provided by the service should be three times per week, however not every area receives it, due to the particular geographic morphology and the unorganized collection methodology. Comparing the answers of Question 2 with the ones of Question 5 can be noted that good efficiency is recognized in the same percentage that receive the service three or more times per week (38.61\% and $41.77 \%$, respectively). Statistical correlation was not introduced, so the data presented is only qualitative. However, the questionnaire suggests that:

- the collection service is not uniform within the city

- some areas receive good service while others are not covered

Question 8 (The citizens are involved into the decisions of new policies about waste management) achieved the poorest results as visible in Figure 2. Indeed, about 50\% of the answers are 'someone' and 'no one'. However, the public service provided some feedback services for citizens or communication platforms in order to directly link the local municipal government with the population. Nevertheless, according to the data obtained, there is a lack of information systems that allow citizens to use this services. So, the answers obtained by this question provided indications of:

- low public participation in SWM practices

- lack of communication systems within the city

Finally, Question 10 was provided within the study for investigating willingness to recycle by the students of the Salesian University. A significant percentage (72\%) would separate waste materials at home or within work spaces, giving good prospects for future practices.

\subsection{Differences between the Case Studies Presented}

The two main topics that should be investigated in the developing country considered are the perception about service equity and inclusion of the informal sector. Indeed, in the context presented, as is usual in low-income countries, these two themes are of utmost importance, as are widespread 
in the region. Informal sector inclusion and the equity of the collection systems could be the answer to achieve a sustainable SWM service, appropriate for the health of the citizens in a framework of environmental and social sustainability. On the other hand, the studies within the developed country suggested the public opinion should be considered concerning technological facilities, since the public commonly disagree on the introduction of treatment systems near urban centers. This happens due to the past bad experiences with facility mismanagement which polluted the environment and which did not encourage public opinion to accept the development of future activities. Moreover, in this high-income country, years of experiences and information programs have increased public awareness, resulting in spreading public perception of environmental issues. Such considerations are not exportable to developing countries where sanitary services are still lacking.

Opinions about the service and the sensitivity about ecological topics could be assessed in both developed and developing countries, although in a different manner, considering that the public perceptions differ area by area. In addition, information about recycling behavior could be surveyed within questionnaire researches, with the difference that in a low-income country such information is required in order to assess future programs, while in a high-income country it is essential to evaluate current recovery activities. Since in La Paz the meaning of 'selective collection' or 'separate waste fractions' is mostly unknown to the citizens, the shape of the question should be chosen with accuracy, according to public perception on solid waste materials.

The considerations introduced within this paper focus on which topics are of interest for stakeholders for implementing a questionnaire survey in a specific area. The main objective is always the evaluation of public perspective in past, current, and future programs - which include technological, financial, and political issues-in order to develop projects suited for the citizens, actors who will be the users and the direct targets of every positive and negative change.

\section{Discussion}

Among other factors, such as financial incentives [52], policy implementation, and technology development, a real challenge for local authorities is the design of campaigns to promote the use of waste separation programs in order to increase waste recovery rates [53]. Assessing students' behavior enables improvement of campaigns that emphasize recycling practices and solid waste recovery plans, which is useful to reduce waste inflow to landfills and to save economic resources [54]. For instance, disclosure of specific information within specific areas helps people to understand the importance of the introduction of treatment facilities, recycling plants, collection methodology, etc. Indeed, solutions for SWM are not simply a technical issue but are also an organizational concern and there is a central requisite to improve citizens participation [10]. Assessing local behavior in environmental themes is essential for evaluating public involvement and degree of interest within the area, as the introduction of new policies and collection methodologies into the SWM requires public involvement [2]. Stimulating waste reduction at the source and recycling of various materials is recommended in order to introduce sustainable practices both in developed and developing countries [40]. Hence, more initiatives to promote waste recycling and ecological awareness should be provided, especially in developing countries, where behavior change in addressing environmental problems is considered very critical [55]. These practices can start from higher education institutes, through implementation of sustainable activities in public and private facilities for example. However, to ensure high participation rates, local authorities should design waste separation programs that suit the needs of the population [53]. For introducing MSW policy it is therefore important to analyze how people act in different situations and settings since it is necessary to find and introduce a system which is both organizationally and technically appropriate [56].

It has been demonstrated by life cycle studies that the introduction of recycling processes within higher education institutes helps to reduce global warming potential and solid waste services costs [41]. In the same studies it has been revealed that there is a significant potential for improving the environmental performance and cost operations of universities. However, specific studies should 
be conducted in order to respect and understand the social, cultural, and economic characteristics of each area, as proposed in the present work. Indeed, local social acceptability and environmental compatibility ought to be assessed for promoting an equitable and sustainable society [57] inasmuch as selected collection organized at a household level and supported by targeted awareness campaigns should increase recycling rates and waste recovery [58]. Nevertheless, at the same time, financial sustainability of the recycling chain should be evaluated, since economic advantages are achievable up to a certain recycling rate [59].

\subsection{SWM Behavior in Developed and Developing Countries}

The introduction of a reverse logistic system, useful for improving SWM within a city, must overcome issues which include financial sustainability, market competitiveness, managerial subjects, labor concerns, and regulations for implementation [60]. However, the effectiveness of any MSW management scheme and its smooth operation heavily depends on its acceptance by local communities [61]. Social surveys allow the structuring and collecting of information to develop a baseline knowledge of what is happening in cities and provide advice about the factors influencing SWM systems for authorities and stakeholders interested in planning [32]. As a result, consideration of social aspects in the investigated decision support tools led to the selection of the most sustainable option and improved the evaluation of social aspects [62]. Indeed, questionnaires and face-to-face interviews of citizens allow the municipality to quantify the generation, average product life span, disposal practice, and willingness to contribute for MSW at a household level, including the results of international regulation and waste generation trends $[63,64]$. Four main dimensions are commonly included within social surveys-political, financial, socio-cultural, and technological—which have great influence on effectiveness of the selective collection of MSW [65].

In this paper, two approaches were examined: one in a developed country, where knowledge and technological practices are noted for the high percentage of recycling rate introduced by local authorities; and one in a developing country, where recycling rates and SWM organization is generally poor. This comparison helps develop an understanding of which approach is suited for each area, and which difficulties are founded. Moreover, the comparison has been carried out for evaluating different students' behavior in the same country with similar recycling rates but in different social contexts. This allows us to study the applicability level of a particular system within a specific area. So, the comparison is useful to highlight differences with a developing country and also within the same country.

Questionnaire assessment programs shall be used to evaluate social acceptance of new projects, barriers, and obstacles which must be overcome to ensure project sustainability [66]. Social surveys are recommended in other studies in order to find out whether there are issues related to the correct application of SWM inside public facilities [36]. Particularly, in this case study, assessment of students' knowledge and acceptance concerning SWM practices allows stakeholders and planners to understand where recycling systems should be improved, both in developed and developing countries, while considering different culture and habits. Indeed, this survey suggests the use of different approaches in social investigation for considering different SWM activities and behavior.

Involvement of local universities and authorities is recommended for improving and understanding current needs within SWM practices at a household level [67]. Indeed, the survey in La Paz brings to light typical difficulties found in emerging big cities such as uneven availability of service, low public participation, lack of social inclusion, and low service quality perceptions by the population [68]. Social surveys also allow experts to confirm or deepen general studies applied within a region since solutions need to be developed including local needs and sustainable social aspects, minimizing conflict between stakeholders and promoting the social acceptability of management activities [69]. Users and potential users must be involved in designing their own service, provided that the cost is locally affordable [23]. 
The comparison of a high-income and low-income country led to understanding which factors need to be improved and what is significant to consider for a social survey. How suited is the approach used within a specific area in order to evaluate public preliminary knowledge and problem perception? This is the issue analyzed in this paper, suggesting particular precautions in SWM according to the needs of local societies.

\subsection{Strengths and Weaknesses of the Surveys}

The sample analyzed cannot be considered representative of all the students and young people of the cities. However, the aim of the study is to compare the methodologies that should be developed for introducing suitable approaches in each study area and introduce some considerations about the results obtained.

Some questions introduced within the Italian survey have answers that are more correct than others because the high income level and the long SWM process introduced in the country allows an a priori understanding of which answer might be given. For instance, for the question "What do the components separated from MSW represent to you?" it is easy to expect that the answer given by the students is the second ('material to recycle') as the recycling rate is quite high in both cities; again, for the question "Who among these actors has to be part of the siting process of a landfill or an incinerator?" we expect answer 3 ('technicians, politicians, and citizens') as symptom of social inclusion, according to other studies, where the concept of public integration in the decision-making process for the introduction of exploitation facilities within an urban area has been introduced [70]. This concept cannot be confirmed for the La Paz case study, and generally for developing countries worldwide, where the recycling rates are low, SWM practices are recent, and public participation is still missing. Difficulties in the implementation of structured surveys increase with poor income states, low education level, low public knowledge, and absence of organized SWM.

As a general consideration for the emerging reality, the introduction of the survey to university students is significant in order to motivate and explain the questions that could be more difficult to understand and the reason why the study is significant for future programs. This has been implemented within Salesian University, achieving a high level of awareness and interest in the students.

After this survey, the questionnaire submitted at the Salesian University may be modified and provided to other local universities in order to evaluate more characteristics of the service provided. Indeed, more samples could be provided for introducing more comparative data also between Bolivian Universities and departments, as suggested by De Feo and Williams [45] for the case study of Salerno. In addition, statistical studies can be included in the survey in order to correlate students' age and sex, household dimension, and income level with the answers obtained. Finally, correlation between 'before' and 'after' sensitivity activities can be introduced in these realities to understand which component can be improved for developing recycling rates within the city, as suggested in other studies in developing countries [13].

\section{Conclusions}

Two approaches about social surveys in developing and developed countries were presented and discussed. The objective of the work was to evaluate the suitability of the surveys in higher education institutes, comparing the methods applied with a qualitative approach. The study led to understanding the difficulties and the weaknesses in the provision of a questionnaire which is used to assess social behavior within different income and cultural areas, as suggested by the comparison between Varese and Salerno or with an emerging city and a developed one. The paper also provided the comparison between universities in areas with different culture and income levels which means, from a solid waste perspective, the difference between high and low recycling rates.

The survey states that La Paz is faced with low public inclusion; informal recycling activities unrecognized, poor, and uneven waste collection practices; and low public awareness. 
Many students (about 53\%) do not know the recycling practices implemented by waste pickers or state that informal activities never occur within the city, although they are widespread within the city and many recovery shops are present in the area. As regards the collection system, more than $40 \%$ of the interviewed affirm that the service is provided only two or less days per week, with a 7\% that answering 'never'. The collection time provided by the service should be three times per week, so the result suggested how the collection system is not uniform in the city. Moreover, the poorest result has been obtained in relation to the citizens' involvement in the decision-making procedures for the introduction of new policies about waste management, since about $50 \%$ of the answers are 'someone' and 'no one'. Anyhow, a significant percentage (72\%) would separate waste materials at home or within work spaces, giving a good prospective for future practices

On the contrary, low technological acceptance is underlined in the high-income country due to bad past experiences and many differences also are visible within the comparison between the two Italian universities, clearly as a function of social behavior and cultural basis. There is a common opinion concerning introduction of landfills and incinerators near residential areas as $49 \%$ of students do not agree with the introduction of both technologies. Indeed, public acceptance is considered most critical for alternatives widely debated such as waste-to-energy where the "Not In My Back Yard" (NIMBY) syndrome is widespread. As regards public participation, both universities' students agree about the integration of public compounds within policy planning (more than 50\%). Knowledge evaluation about MSW led to an understand of the differences in waste behaviors: $45.40 \%$ of Insubria students stated that plastic is the MSW most produced even if the correct answer is 'putrescible waste', mostly chosen correctly by students from Salerno ( $47.11 \%)$. The answer given to the question related to the meaning of RDF is significant, since at University of Insubria the right answer was given by $60 \%$ of respondents, unlike University of Salerno, where the answer 'I do not know' was the most given $(40.22 \%)$; the result is in accordance with the current SWM practice implemented in Lombardia, which is the region where Refuse Derived Fuels (RDF) are most consumed and produced in Italy.

According to the results obtained in this study, one of the main issues related to MSW involves public awareness and opinions about current collection and management activities. Moreover, public acceptance of new technological facilities should be considered in order to avoid conflict with local citizens and low reliability of the systems introduced. Generally, it is important to provide a service which is equal and uniform, since it is required for guaranteeing service also in poorest or farthest areas. As a result, before applying new polices and building new expensive technological facilities, enhancing public understanding is of utmost importance. Higher education institutes are structures where the beginning of these approaches can be applied as highly-educated people can help in increasing the number of 'green citizens', aiding the municipality to apply programs in line with the principles of a circular economy and sustainable development. For that purpose, we suggest introducing awareness campaigns, supported by social surveys, within universities and higher education institutes, in developed countries as in developing ones, in order to build a recycling chain that starts from young citizens with higher education levels, who can directly influence households and public perception in environmental subjects.

Acknowledgments: The authors wish to thank Antonio Ferronato and the Salesian University of La Paz, particularly the Rector Padre T. Corona C. for the survey support.

Author Contributions: All authors contributed equally to the survey presented in this paper.

Conflicts of Interest: The authors declare no conflict of interest.

\section{References}

1. Wilson, D.C.; Rodic, L.; Modak, P.; Soos, R.; Carpintero, A.; Velis, C.A.; Iyer, M.; Simonett, O. Global Waste Management Outlook; International Environment Technology Centre: Nairobi, Kenya, 2015.

2. Vaccari, M.; Di Bella, V.; Vitali, F.; Collivignarelli, C. From mixed to separate collection of solid waste: Benefits for the town of Zavidovići (Bosnia and Herzegovina). Waste Manag. 2013, 33, 277-286. [CrossRef] [PubMed] 
3. Rada, E.C.; Ragazzi, M.; Ionescu, G.; Merler, G.; Moedinger, F.; Raboni, M.; Torretta, V. Municipal Solid Waste treatment by integrated solutions: Energy and environmental balances. Energy Procedia 2014, 50, 1037-1044. [CrossRef]

4. Ragazzi, M.; Rada, E.C. Effects of recent strategies of selective collection on the design of municipal solid waste treatment plants in Italy. WIT Trans. Ecol. Environ. 2008, 109, 613-620.

5. Kollikkathara, N.; Feng, H.; Stern, E.A. Purview of waste management evolution: Special emphasis on USA. Waste Manag. 2009, 29, 974-985. [CrossRef] [PubMed]

6. Khoo, H.H. Life cycle impact assessment of various waste conversion technologies. Waste Manag. 2009, 29, 1892-1900. [CrossRef] [PubMed]

7. Moh, Y.C.; Manaf, L.A. Overview of household solid waste recycling policy status and challenges in Malaysia. Resour. Conserv. Recycl. 2014, 82, 50-61. [CrossRef]

8. Torretta, V.; Ferronato, N.; Katsoyiannis, I.A.; Tolkou, A.K.; Airoldi, M. Novel and Conventional Technologies for Landfill Leachates Treatment: A Review. Sustainability 2016, 9, 9. [CrossRef]

9. Imam, A.; Mohammed, B.; Wilson, D.C.; Cheeseman, C.R. Solid waste management in Abuja, Nigeria. Waste Manag. 2008, 28, 468-472. [CrossRef] [PubMed]

10. Narayana, T. Municipal solid waste management in India: From waste disposal to recovery of resources? Waste Manag. 2009, 29, 1163-1166. [CrossRef] [PubMed]

11. Moghadam, M.A.; Mokhtarani, N.; Mokhtarani, B. Municipal solid waste management in Rasht City, Iran. Waste Manag. 2009, 29, 485-489. [CrossRef] [PubMed]

12. Oteng-Ababio, M.; Arguello, J.E.M.; Gabbay, O. Solid waste management in African cities: Sorting the facts from the fads in Accra, Ghana. Habitat Int. 2013, 39, 96-104. [CrossRef]

13. Pakpour, A.H.; Zeidi, I.M.; Emamjomeh, M.M.; Asefzadeh, S.; Pearson, H. Household waste behaviors among a community sample in Iran: An application of the theory of planned behavior. Waste Manag. 2014, 34, 980-986. [CrossRef] [PubMed]

14. Schiavon, M.; Ragazzi, M.; Rada, E.C.; Merler, G. Proposal for the correct management of the life cycle assessment results from integrated municipal solid waste treatment. WIT Trans. Ecol. Environ. 2014, 180, 163-173.

15. Song, Q.; Wang, Z.; Li, J. Residents' Attitudes and Willingness to Pay for Solid Waste Management in Macau. Procedia Environ. Sci. 2016, 31, 635-643. [CrossRef]

16. Tabernero, C.; Hernández, B.; Cuadrado, E.; Luque, B.; Pereira, C.R. A multilevel perspective to explain recycling behavior in communities. J. Environ. Manag. 2015, 159, 192-201. [CrossRef] [PubMed]

17. Borgstede, C.; Biel, A. Pro-environmental behavior: Situational barriers and concern for the good at stake. Göteborg Psychol. Rep. 2002, 32, 1-10.

18. Corraliza, J.; Berenguer, J. Environmental values, beliefs and actions. A situational approach. Environ. Behav. 2000, 32, 832-848. [CrossRef]

19. Suttibak, S.; Nitivattananon, V. Assessment of factors influencing the performance of solid waste recycling programs. Resour. Conserv. Recycl. 2008, 53, 45-56. [CrossRef]

20. Torretta, V.; Ragazzi, M.; Istrate, I.A.; Rada, E.C. Management of waste electrical and electronic equipment in two EU countries: A comparison. Waste Manag. 2013, 33, 117-122. [CrossRef] [PubMed]

21. Thomas, C. Public understanding and its effects on recycling performance in Hampshire and Milton Keynes. Resour. Conserv. Recycl. 2001, 32, 259-274. [CrossRef]

22. Verdugo, V.C. The positive psychology of sustainability. Environ. Dev. Sustain. 2012, 14, 651-666. [CrossRef]

23. Wilson, D.C.; Velis, C.A.; Rodic, L. Integrated sustainable waste management in developing countries. Waste Manag. Resour. 2013, 166, 52-68. [CrossRef]

24. Tonglet, M.; Phillips, P.S.; Read, A.D. Using the Theory of Planned Behavior to investigate the determinants of recycling behavior: A case study from Brixworth, UK. Resour. Conserv. Recycl. 2004, 41, 191-214. [CrossRef]

25. Martin, M.; Williams, I.D.; Clark, M. Social, cultural and structural influences on household waste recycling: A case study. Resour. Conserv. Recycl. 2006, 48, 357-395. [CrossRef]

26. Barr, S.; Gilg, A.W.; Ford, N.J. Differences between household waste reduction, reuse and recycling behavior: A study of reported behaviors, intentions and explanatory variables. Environ. Waste Manag. 2001, 4, 69-82.

27. Al Sabbagh, M.K.; Velis, C.A.; Wilson, D.C.; Cheeseman, C.R. Resource management performance in Bahrain: A systematic analysis of municipal waste management, secondary material flows and organizational aspects. Waste Manag. Res. 2012, 30, 813-824. [CrossRef] [PubMed] 
28. Robinson, G.M.; Read, A.D. Recycling behavior in a London Borough: Results from large-scale household surveys. Resour. Conserv. Recycl. 2005, 45, 70-83. [CrossRef]

29. De Feo, G. Sociological survey in a municipality with a high level separate collection program in an area of historic unpopularity. Waste Manag. 2014, 34, 1369-1380. [CrossRef] [PubMed]

30. Bamberg, S. How does environmental concern influence specific environmentally related behaviors? A new answers to an old question. J. Environ. Psychol. 2003, 23, 21-32. [CrossRef]

31. Michalos, A.C.; Creech, H.; McDonald, C.; HatachKahlke, P.M. Measuring Knowledge, Attitudes and Behaviors towards Sustainable Development: Two Exploratory Studies; International Institute for Sustainable Development (IISD): Winnipeg, MB, Canada, 2009.

32. Guerrero, L.A.; Maas, G.; Hogland, W. Solid waste management challenges for cities in developing countries. Waste Manag. 2013, 33, 220-232. [CrossRef] [PubMed]

33. De Feo, G.; Polito, A.R. Using economic benefits for recycling in a separate collection center managed as a "reverse supermarket": A sociological survey. Waste Manag. 2015, 38, 12-21. [CrossRef] [PubMed]

34. Lakatos, E.S.; Dan, V.; Cioca, L.I.; Bacali, L.; Ciobanu, A.M. How Supportive Are Romanian Consumers of the Circular Economy Concept: A Survey. Sustainability 2016, 8, 789. [CrossRef]

35. Lambert, R. Lambert Review of Business-University Collaboration: Final Report. Available online: http:/ /www. eua.be/eua/jsp/en/upload/lambert_review_final_450.1151581102387.pdf (accessed on 10 November 2016).

36. Rada, E.C.; Bresciani, C.; Girelli, E.; Ragazzi, M.; Schiavon, M.; Torretta, V. Analysis and Measures to Improve Waste Management in Schools. Sustainability 2016, 8, 840. [CrossRef]

37. Stephens, J.C.; Hernandez, M.E.; Roman, M.; Graham, A.C.; Scholz, R.W. Higher education as a change agent for sustainability in different cultures and contexts. Int. J. Sustain. High. Educ. 2008, 9, 317-338. [CrossRef]

38. Jain, S.; Aggarwal, P.; Sharma, N.; Sharma, P. Fostering sustainability through education, research and practice: A case study of TERI University. J. Clean. Prod. 2013, 61, 20-24. [CrossRef]

39. Alshuwaikhat, H.M.; Abubakar, I. An integrated approach to achieving campus sustainability assessment of the current campus environmental management practices. J. Clean. Prod. 2008, 16, 1777-1785. [CrossRef]

40. De Castro, R.; Jabbour, C.J.C. Evaluating sustainability of an Indian university. J. Clean. Prod. 2013, 61, 54-58. [CrossRef]

41. Lukman, R.; Tiwary, A.; Azapagic, A. Towards greening a university campus: The case of the University of Maribor, Slovenia. Resour. Conserv. Recycl. 2009, 53, 639-644. [CrossRef]

42. Smyth, D.P.; Fredeen, A.L.; Booth, A.L. Reducing solid waste in higher education: The first step towards 'greening' a university campus. Resour. Conserv. Recycl. 2010, 54, 1007-1016. [CrossRef]

43. Iojă, C.I.; Onose, D.A.; Grădinaru, S.R.; Şerban, C. Waste management in public educational institutions of Bucharest city, Romania. Procedia Environ. Sci. 2012, 14, 71-78. [CrossRef]

44. Zotos, G.; Karagiannidis, A.; Zampetoglou, S.; Malamakis, A.; Antonopoulos, I.S.; Kontogianni, S. Tchobanoglous, G. Developing a holistic strategy for integrated waste management within municipal planning: Challenges, policies, solutions and perspectives for Hellenic municipalities in the zero-waste, low-cost direction. Waste Manag. 2009, 29, 1686-1692. [CrossRef] [PubMed]

45. De Feo, G.; Williams, I. Siting landfills and incinerators in areas of historic unpopularity: Surveying the views of the next generation. Waste Manag. 2013, 33, 2798-2810. [CrossRef] [PubMed]

46. Comune di Varese (CVa). 2016. Available online: http://www.comune.varese.it/popolazione-residente (accessed on 10 November 2016).

47. United Nations Statistics Division (UNSD). 2007. Available online: http://data.un.org/ (accessed on 10 November 2016).

48. Anagrafe Nazionale Studenti (ANS). 2015. Available online: http://anagrafe.miur.it/ (accessed on 12 November 2016).

49. Wilson, D.C.; Rodic, L.; Cowing, M.J.; Velis, C.A.; Whiteman, A.D.; Scheinberg, A.; Vilches, R.; Masterson, D.; Stretz, J.; Oelz, B. 'Wasteaware' benchmark indicators for integrated sustainable waste management in cities. Waste Manag. 2015, 35, 329-342. [CrossRef] [PubMed]

50. ISPRA. Rapporto Rifiuti Urbani, Edizione 2015. Istituto Superiore per la Protezione e la Ricerca Ambientale. 2015. Available online: http:/ / www.isprambiente.gov.it (accessed on 12 November 2016).

51. Karim Ghani, W.A.; Rusli, I.F.; Biak, D.R.; Idris, A. An application of the theory of planned behavior to study the influencing factors of participation in source separation of food waste. Waste Manag. 2013, 33, 1276-1281. [CrossRef] [PubMed] 
52. Marques, R.C.; da Cruz, N.F.; Simões, P.; Ferreira, S.F.; Pereira, M.C.; De Jaeger, S. Economic viability of packaging waste recycling systems: A comparison between Belgium and Portugal. Resour. Conserv. Recycl. 2014, 85, 22-33. [CrossRef]

53. Bari, Q.H.; Hassan, K.M.; Haque, R. Scenario of solid waste reuse in Khulna city of Bangladesh. Waste Manag. 2012, 32, 2526-2534. [CrossRef] [PubMed]

54. Maldonado, L. Reducción y reciclaje de residuos sólidos urbanos en centros de educación superior: Estudio de caso. Rev. Ing. 2006, 10, 59-68.

55. Oyekale, A.S. Factors Explaining Households' Cash Payment for Solid Waste Disposal and Recycling Behaviors in South Africa. Sustainability 2015, 7, 15882-15899. [CrossRef]

56. Refsgaard, K.; Magnussen, K. Household behavior and attitudes with respect to recycling food waste-Experiences from focus groups. J. Environ. Manag. 2009, 90, 760-771. [CrossRef] [PubMed]

57. Sukholthaman, P.; Sharp, A. A system dynamics model to evaluate effects of source separation of municipal solid waste management: A case of Bangkok, Thailand. Waste Manag. 2016, 52, 50-61. [CrossRef] [PubMed]

58. Mgaya, P.; Nondek, L. Disposal frequencies of selected recyclable wastes in Dar es Salaam. Waste Manag. 2004, 24, 927-933. [CrossRef] [PubMed]

59. Da Cruz, N.F.; Ferreira, S.; Cabral, M.; Simões, P.; Marques, R.C. Packaging waste recycling in Europe: Is the industry paying for it? Waste Manag. 2014, 34, 298-308. [CrossRef] [PubMed]

60. Pumpinyo, S.; Nitivattananon, V. Investigation of Barriers and Factors Affecting the Reverse Logistics of Waste Management Practice: A Case Study in Thailand. Sustainability 2014, 6, 7048-7062. [CrossRef]

61. Achillas, C.; Vlachokostas, C.; Moussiopoulos, N.; Banias, G.; Kafetzopoulos, G.; Karagiannidis, A. Social acceptance for the development of a waste-to-energy plant in an urban area. Resour. Conserv. Recycl. 2011, 55, 857-863. [CrossRef]

62. Cappuyns, V. Inclusion of social indicators in decision support tools for the selection of sustainable site remediation options. J. Environ. Manag. 2016, 184, 45-56. [CrossRef] [PubMed]

63. Islam, M.T.; Abdullah, A.B.; Shahir, S.A.; Kalam, M.A.; Masjuki, H.H.; Shumon, R.; Rashid, M.H. A public survey on knowledge, awareness, attitude and willingness to pay for WEEE management: Case study in Bangladesh. J. Clean. Prod. 2016, 137, 728-740. [CrossRef]

64. Barr, S. Factors influencing environmental attitudes and behaviors: A UK case study of household waste management. Environ. Behav. 2007, 39, 435-473. [CrossRef]

65. Chu, Z.; Wang, W.; Wang, B.; Zhuang, J. Research on Factors Influencing Municipal Household Solid Waste Separate Collection: Bayesian Belief Networks. Sustainability 2016, 8, 152. [CrossRef]

66. Zurbrügg, C.; Gfrerer, M.; Ashadi, H.; Brenner, W.; Küper, D. Determinants of sustainability in solid waste management-The Gianyar Waste Recovery Project in Indonesia. Waste Manag. 2012, 32, 2126-2133. [CrossRef] [PubMed]

67. Ferronato, N.; Bezzi, M.; Zortea, M.; Torretta, V.; Ragazzi, M. An interdisciplinary approach for introducing sustainable integrated solid waste management system in developing countries: The case of La Paz (Bolivia). Procedia Environ. Sci. Eng. Manag. 2016, 3, 71-81.

68. Wilson, D.C.; Rodic, L.; Scheinberg, A.; Velis, C.A.; Alabaster, G. Comparative analysis of solid waste management in 20 cities. Waste Manag. Res. 2012, 30, 237-254. [CrossRef] [PubMed]

69. Ives, C.D.; Kendal, D. The role of social values in the management of ecological systems. J. Environ. Manag. 2014, 144, 67-72. [CrossRef] [PubMed]

70. Jenkins-Smith, H.C.; Silva, C.L.; Nowlin, M.C.; De Lozier, G. Reversing nuclear opposition: Evolving public acceptance of a permanent nuclear waste disposal facility. Risk Anal. 2011, 31, 629-644. [CrossRef] [PubMed]

(c) 2017 by the authors. Licensee MDPI, Basel, Switzerland. This article is an open access article distributed under the terms and conditions of the Creative Commons Attribution (CC BY) license (http://creativecommons.org/licenses/by/4.0/). 